\title{
The Chrysidoidea Wasps (Hymenoptera, Aculeata) in Conventional Coffee Crops and Agroforestry Systems in Southeastern Brazil
}

\author{
André Luis Martins'; José Ricardo Assmann Lemes ${ }^{2}$; Paulo Rogério Lopes ${ }^{3}$ \& Angélica Maria Penteado Dias ${ }^{4}$
}

\author{
1 Universidade Federal do Paraná (UFPR), Setor de Ciências Biológicas (BL), Departamento de Zoologia (DZO0), Laboratório de Biologia \\ Comparada de Hymenoptera (LBCH). Curitiba, PR, Brasil. ORCID: http://orcid.org/0000-0002-4794-0644. E-mail: andrelm3048@gmail.com \\ 2 Universidade Federal do Paraná (UFPR), Setor de Ciências Biológicas (BL), Departamento de Zoologia (DZO0), Laboratório de Estudos de \\ Lepidoptera Neotropical (LABLEP). Curitiba, PR, Brasil. ORCID: http://orcid.org/0000-0003-1107-7903. E-mail: jralemes@gmail.com \\ 3 Universidade Federal do Paraná (UFPR), Setor Litoral (SL), Câmara do Curso de Agroecologia. Matinhos, PR, Brasil. \\ ORCID: http://orcid.org/0000-0003-1454-7202. E-mail: paulolopes@ufpr.br \\ ${ }^{4}$ Universidade Federal de São Carlos (UFSCAR), Centro de Ciências Biológicas e da Saúde (CCBS), Departamento de Ecologia e \\ Biologia Evolutiva (DEBE). São Carlos, SP, Brasil. ORCID: http://orcid.org/0000-0002-8371-5591. E-mail: angelica@ufscar.br
}

\begin{abstract}
Agroforestry systems represent the integration of agricultural crops with native vegetation. These systems are of great importance to minimize the agricultural impact in the land through intercropping of these vegetations. Despite of the importance of Chrysidoidea as parasitoids wasps associated with different groups of insects, there is no study comparing the assemblages of these hymenopterans in conventional and agroforestry systems in southeastern Brazil. The "Pontal do Paranapanema", located in the extreme west of the state of São Paulo (Brazil), has historically been occupied by coffee crops and some small areas of agroforestry systems. Therefore, this study aimed to verify the abundance and composition of Chrysidoidea wasp fauna in different conventional coffee crops and agroforestry systems located in this region. To do so, we collected in six different localities in the "Pontal do Paranapanema" using a Malaise trap in each locality, with collections occurring monthly between June 2011 and July 2012. A total of 3,623 Chrysidoidea specimens of three families were collected: Bethylidae, with four genera and 3,396 individuals, representing 93.73\% of the total collected; Chrysididae with 11 genera and 151 individuals (4.16\%), and Dryinidae with five genera and 76 individuals (2.09\%). In terms of abundance, the agroforestry was responsible for most of the individuals collected $(n=2029)$, followed by the conventional systems with 1,406 individuals and the transitional with 188. The most abundant genera were Epyris and Dissomphalus, responsible for about $92 \%$ of the total of Chrysidoidea collected. Most of the genera of Chrysididae were collected in the conventional systems alone or in both conventional and agroforestry systems. For Bethylidae and Dryinidae, no genera were found exclusively in the conventional system. It is expected that the structural complexity of each one of the different ecosystems impact directly in the fauna of Chrysidoidea parasitoids associated.
\end{abstract}

Key-Words. Bethylidae; Chrysididae; Dryinidae; Malaise trap; Parasitoids.

\section{INTRODUCTION}

Degradation, fragmentation and destruction of habitats play central roles among the pressures driving biodiversity loss (Rands et al., 2010; Haddad et al., 2015). The conversion of native vegetation to agricultural systems has been the most important disturbance of natural ecosystems caused by human activities (Pereira et al., 2010; Foley et al., 2011). With continued population growth, agricultural demand is necessary to guarantee future food security (Foley et al., 2011).

Coffee is considered the most important commodity in the world after oil. Besides that, Brazil is the most important country that produces and exports coffee worldwide (Fernandes et al., 2012; Volsi et al., 2019; Macedo et al., 2020). The conventional coffee farming has adopted increasingly intensive management in agrochemicals. This style of coffee farming has as its main characteristics the simplification of agroecosystems (monoculture), with periodic use of pesticides and synthetic fertilizers, causing negative environmental, ecological, health and social consequences and implications (Lopes et al., 2012).

Preservation of native vegetation into land use systems, such as in agroforestry, is an interesting sustainable alternative in this scenario (SteffanDewenter et al., 2007; McGinty et al., 2008; Negawo \& Beyene, 2017). In addition to maintain- 
ing the balance of biodiversity through the association of different cultures, allowing the existence of different pest control agents, agroforestry systems were created primarily to optimize land use, reconciling forest production with food production, conserve soil and reduce land pressure caused by agricultural production. (Engel, 1999; Meirelles, 2003).

Agroforestry systems are productive systems with greater biological complexity (consortia and polycultures) composed by the integration of diversified species of trees and shrubs with agricultural crops and tend to be more efficient, sustainable, resilient and productive (Meirelles, 2003; Altieri, 2012; Paludo \& Costabeber, 2012; Lopes et al., 2014; Martínez-Salinas, 2016). In complex and diversified agroforestry there are great difficulties to manage the system in a more sustainable way, due to the diversification of species that are little known. Simplified systems are easier in this regard, but most are unsustainable, allowing decreases or even losses in the abundance of organisms, in special to insects such as the parasitoids, which control populations of other insects that cause damage to the crops (Meirelles, 2003).

Hymenoptera, represented by ants, bees and wasps, is an important group of insects present in all terrestrial environments, including agroforestry systems (Hanson $\&$ Gauld, 2006). These insects play an important role in pest control and commercial production (Hanson \& Gauld, 2006; Heraty et al., 2011). Among Hymenoptera, the parasitoid wasps of the superfamily Chrysidoidea, composed by the living families Bethylidae, Chrysididae, Dryinidae, Embolemidae, Plumariidae, Sclerogibbidae and Scolebythidae (Brothers, 2006), are associated with different groups of hosts, like Embioptera, Lepidoptera, Coleoptera, Hemiptera, Hymenoptera and Phasmatodea (Azevedo \& Helmer, 1999; Brothers, 2006; Fernández, 2006; Hanson \& Gauld, 2006; Melo et al., 2012; Guglielmino et al., 2013; Martins \& Domahovski, 2017a, b; MoralesSilva et al., 2019; Martins et al., 2020). The diversity of this superfamily is estimated at approximately 16,000 species, of which about 8,000 are described (Azevedo et al., 2018; Olmi et al., 2019; Pauli et al., 2019; Chény et al., 2020). Among the families of Chrysidoidea, three are considered the most diverse: Bethylidae with 96 genera and about 2,920 species, Chrysididae with 110 genera and about 3,000 species, and Dryinidae with 52 genera and 1,900 species (Azevedo et al., 2018; Olmi et al., 2019; Pauli et al., 2019). The other Chrysidoidea families are less diverse, little known and rarely collected (Brothers, 2006; Melo et al., 2012).

There are some studies investigating the Chrysidoidea fauna in southeastern Brazil, most of them related to faunistic fauna associated with the Atlantic Forest, especially in the states of Espírito Santo, Paraná and São Paulo (Azevedo \& Helmer, 1999; Azevedo \& Santos, 2000; Azevedo et al., 2002, 2003, 2006, 2015; Alencar et al., 2007). Others studies focused on the taxonomy of Dryinidae (Martins, 2015, 2018, 2019; Martins et al., 2015a, b, 2020; Martins \& Domahovski, 2017a, b). However, the literature about Chrysidoidea diversity in agroforestry systems is extremely scarce in this region of Brazil (Nakayama et al., 2008). Therefore, this study aimed to verify and compare the occurrence and composition of Chrysidoidea fauna sampled in agroforestry and conventional coffee production systems located in southeastern Brazil.

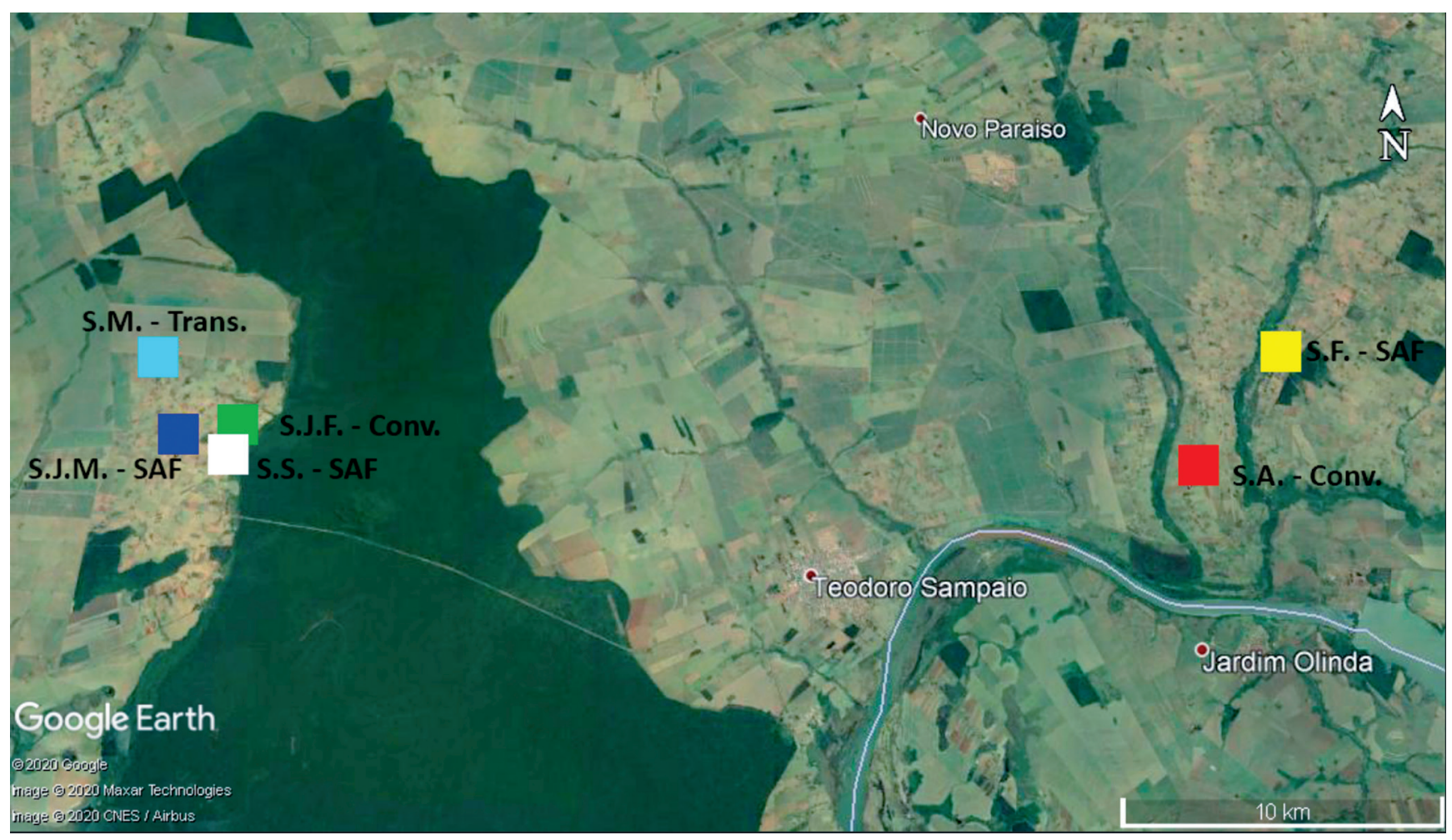

Figure 1. Map showing the collection sites of Chrysidoidea wasps in the conventional, agroforestry and transitional systems in the "Pontal do Paranapanema" area, state of São Paulo, Brazil. The different colored squares represent: S.A. - Conv. (red); S.J.F. - Conv. (green); S.F.- SAF (yellow), S.J.M. - SAF (blue); S.S. - SAF (white); S.M.-Trans. (light blue). 
Table 1. Collection sites of Chrysidoidea wasps of the "Pontal do Paranapanema" region, São Paulo, Brazil.

\begin{tabular}{|c|c|c|c|}
\hline Name of the locality & Geographic coordinates & System & Description \\
\hline "Sítio Antônio" - S.A. - Conv. & $22^{\circ} 30^{\prime} 12^{\prime \prime} \mathrm{S} ; 52^{\circ} 02^{\prime} 57^{\prime \prime} \mathrm{W}$ & Conventional & Coffee monoculture system with application of agrochemicals (area of 3 hectares) \\
\hline "Sítio José Fusca" - S.J.F. - Conv. & $22^{\circ} 29^{\prime} 43^{\prime \prime} \mathrm{S} ; 52^{\circ} 22^{\prime} 03^{\prime \prime} \mathrm{W}$ & Conventional & Coffee monoculture system with application of agrochemicals (area of 0,5 hectare) \\
\hline "Sítio Francisco" - S.F. - SAF & $22^{\circ} 27^{\prime} 59^{\prime \prime} \mathrm{S} ; 52^{\circ} 01^{\prime} 00^{\prime \prime} \mathrm{W}$ & Agroforestry & $\begin{array}{l}\text { Agroforestry system composed of } 32 \text { native tree species, some exotic fruit trees and coffee trees, managed } \\
\text { agroecologically (without chemical inputs) (area of } 1 \text { hectare) }\end{array}$ \\
\hline "Sítio João Moreno" - S.J.M. - SAF & $22^{\circ} 29^{\prime} 40^{\prime \prime} S ; 52^{\circ} 22^{\prime} 56^{\prime \prime} \mathrm{W}$ & Agroforestry & $\begin{array}{l}\text { Agroforestry system composed of } 18 \text { tree species in consortium with coffee trees and agroecological } \\
\text { management (area of } 1 \text { hectare) }\end{array}$ \\
\hline "Sítio Santiago" - S.S. - SAF & $22^{\circ} 29^{\prime} 50^{\prime \prime} \mathrm{S} ; 52^{\circ} 22^{\prime} 06^{\prime \prime} \mathrm{W}$ & Agroforestry & $\begin{array}{l}\text { Agroforestry system composed of } 14 \text { tree species intercropped with coffee trees, with agroecological } \\
\text { management (area of } 1 \text { hectare) }\end{array}$ \\
\hline "Sítio Manoel" - S.M. - Trans. & $22^{\circ} 28^{\prime} 08^{\prime \prime} S ; 52^{\circ} 23^{\prime} 29^{\prime \prime} \mathrm{W}$ & Transitional & $\begin{array}{l}\text { Coffee monoculture system, with hedge formed by native tree species around the stands, received chemical } \\
\text { fertilizers and was free of pesticide use (area of } 2 \text { hectares) }\end{array}$ \\
\hline
\end{tabular}

\section{MATERIAL AND METHODS}

\section{Study area}

This study was carried out in an area named "Pontal do Paranapanema" (Fig. 1), a region historically occupied by large farms based on monoculture and ranching, and recently by the cultivation of sugarcane (Saccharum $\mathrm{sp}$.) and coffee plantations (Coffea arabica L.). This region is also considered the second poorest region of São Paulo (Brazil), basing its economy mainly on the agricultural exploration and the cultivation of sugarcane (Silva et al., 2006; Lopes et al., 2014).

The areas selected for collection of the Hymenoptera parasitoids were agroforestry systems associated with coffee and fruits, and conventional coffee crops at "Fazenda Ribeirão Bonito" (Fig. 1, Table 1), a rural settlement area located near the Morro do Diabo State Park, belonging to the municipality of Teodoro Sampaio, São Paulo, Brazil. One of the collection sites - "Sítio Manoel - S.M.-Trans - was classified as a transitional system. The collections were performed monthly using one Malaise trap model Townes (1972) (Fig. 2) in each of the six localities.

\section{Sampling of Chrysidoidea}

Malaise traps were installed in the central part of the evaluated systems, with one trap per system. The

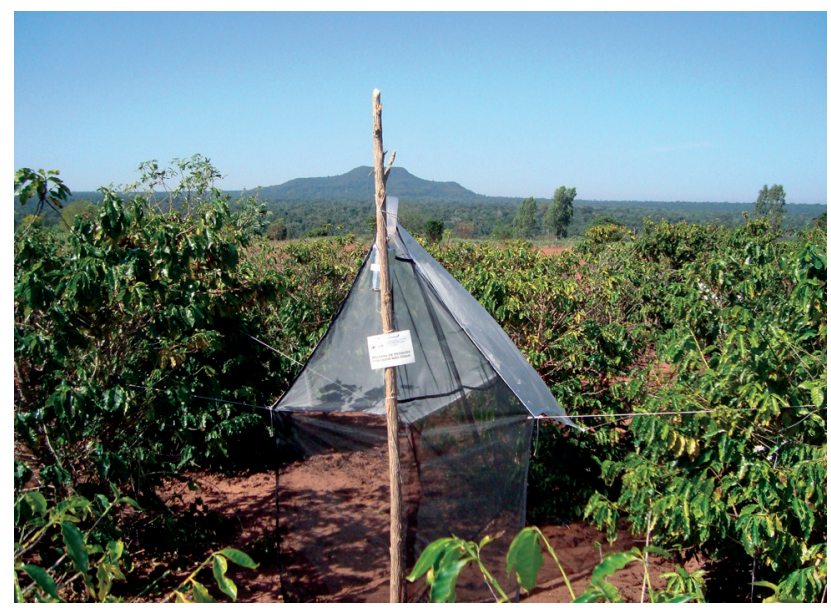

Figure 2. Malaise trap (Townes model) installed in the conventional system (S.J.F. - Conv.), in the "Pontal do Paranapanema" region, São Paulo, Brazil. collections were made every 30 days for a period of 13 months, from June 2011 to July 2012. Every 15 days inspections were carried out on the traps to check for damage and, if necessary, repair or replace them. The Hymenoptera were separated from other insect orders and the Chrysidoidea were identified to genus level using keys proposed by Kimsey (2006), Olmi \& Virla (2014) and Vargas-Rojas \& Terayama (2006). The Chrysididae were sent to Dr. Daercio Lucena, mounted and deposited in the Coleção Entomológica "Prof. João Camargo" of Faculdade de Filosofia, Ciências e Letras de Ribeirão Preto, Ribeirão Preto, São Paulo, Brazil (RPSP; curator Dr. E.A.B. Almeida). Bethylidae and Dryinidae were preserved in $70 \%$ ethanol and deposited in the Coleção de Hymenoptera Parasitoides of Universidade Federal de São Carlos, São Carlos, São Paulo, (DCBU; curator Dr. A.M. Penteado-Dias).

\section{RESULTS AND DISCUSSION}

A total of 3,623 specimens of Chrysidoidea belonging to three families were collected: Bethylidae with four genera and 3,396 individuals, representing $93.73 \%$ of the total collected; Chrysididae with 11 genera and 151 individuals (4.16\%) and Dryinidae with five genera and 76 individuals (2.09\%) (Table 2).

Of the 20 Chrysidoidea genera collected, two were restricted to the conventional systems, all of them belonging to Chrysidinae; three genera were restricted to the agroforestry, one of each family, and no genera was collected exclusively in the transitional system. The conventional systems shared with the agroforestry three genera (one of Bethylidae and two of Dryinidae), and three other genera with the transitional systems, all of them belonging to Chrysididae. The agroforestry shared with the transitional system two genera, one of Bethylidae and one of Dryinidae. Seven genera were found in the three types of systems, one of Bethylidae, one of Dryinidae, and five of Chrysididae (Fig. 3). In terms of abundance, the agroforestry systems were responsible for most of the individuals collected ( $n=2029$ ), followed by the conventional systems with 1,406 individuals and the transitional with 188. Approximately $92 \%$ of this amount is because of the bethylid genera Epyris and Dissomphalus (Table 2).

Bethylidae was the most abundant Chrysidoidea family sampled in several other studies of Hymenoptera 
Table 2. Abundance of the Chrysidoidea genera in the "Pontal do Paranapanema" region, São Paulo, Brazil.

\begin{tabular}{|c|c|c|c|c|c|c|}
\hline Family / Subfamily / Genera & 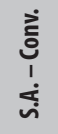 & 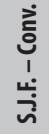 & 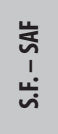 & 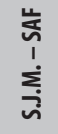 & 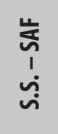 & 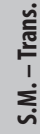 \\
\hline \multicolumn{7}{|l|}{ Bethylidae } \\
\hline \multicolumn{7}{|l|}{ Bethylinae } \\
\hline Goniozus Förster & 0 & 3 & 6 & 5 & 0 & 0 \\
\hline \multicolumn{7}{|l|}{ Epyrinae } \\
\hline Epyris Westwood & 550 & 739 & 438 & 221 & 417 & 129 \\
\hline Bakeriella Kieffer & 0 & 0 & 1 & 6 & 12 & 29 \\
\hline \multicolumn{7}{|l|}{ Pristocerinae } \\
\hline Dissomphalus Ashmead & 0 & 0 & 0 & 35 & 805 & 0 \\
\hline \multicolumn{7}{|l|}{ Chrysididae } \\
\hline \multicolumn{7}{|l|}{ Chrysidinae } \\
\hline Caenochrysis Kimsey \& Bohart & 4 & 9 & 8 & 2 & 3 & 5 \\
\hline Chrysis Linnaeus & 11 & 6 & 6 & 2 & 8 & 1 \\
\hline Elampus Spinola & 10 & 3 & 0 & 0 & 2 & 1 \\
\hline Exallopyga French & 0 & 0 & 2 & 0 & 0 & 0 \\
\hline Hedychrum Latreille & 1 & 0 & 0 & 0 & 0 & 0 \\
\hline Holophris Mocsáry & 0 & 1 & 0 & 0 & 0 & 2 \\
\hline Holopyga Dahlbom & 2 & 7 & 0 & 0 & 0 & 15 \\
\hline Ipsiura Linsenmaier & 3 & 2 & 12 & 1 & 1 & 2 \\
\hline Muesebeckidium Krombein & 0 & 2 & 0 & 0 & 0 & 0 \\
\hline Neochrysis Lisenmeyer & 2 & 1 & 0 & 0 & 0 & 1 \\
\hline Pleurochrysis Bohart & 2 & 4 & 0 & 1 & 5 & 1 \\
\hline \multicolumn{7}{|l|}{ Dryinidae } \\
\hline \multicolumn{7}{|l|}{ Anteoninae } \\
\hline Anteon Jurine & 0 & 0 & 0 & 0 & 1 & 1 \\
\hline Deinodryinus Perkins & 0 & 0 & 0 & 0 & 5 & 0 \\
\hline \multicolumn{7}{|l|}{ Aphelopinae } \\
\hline Aphelopus Dalman & 0 & 2 & 0 & 0 & 1 & 0 \\
\hline \multicolumn{7}{|l|}{ Dryininae } \\
\hline Dryinus Latreille & 1 & 1 & 5 & 4 & 2 & 1 \\
\hline \multicolumn{7}{|l|}{ Gonatopodinae } \\
\hline Gonatopus Ljungh & 2 & 38 & 4 & 5 & 3 & 0 \\
\hline Total & 588 & 818 & 482 & 282 & 1265 & 188 \\
\hline
\end{tabular}

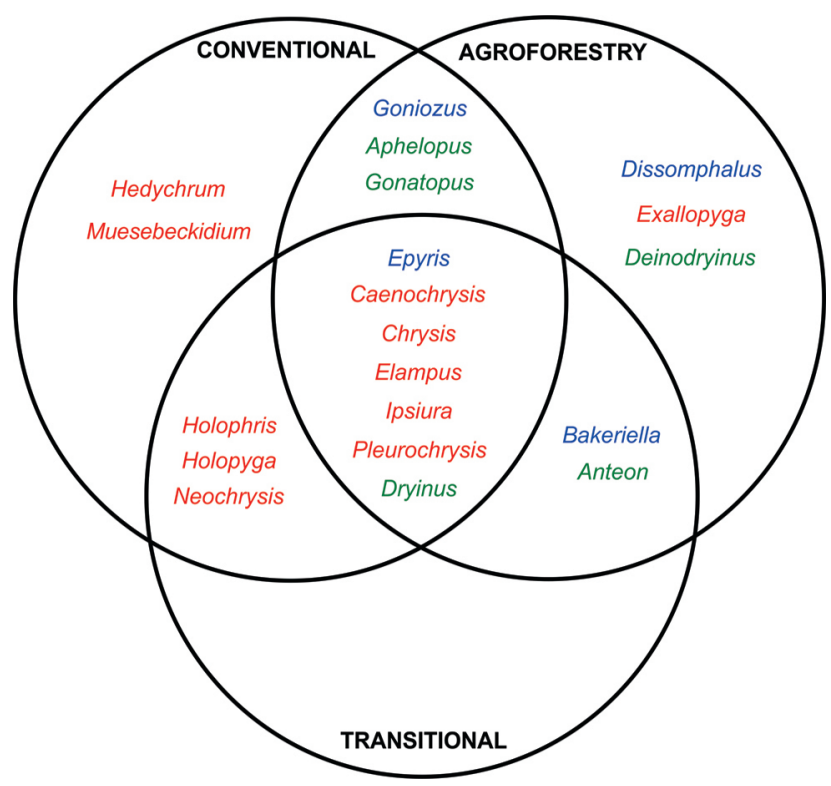

Figure 3. Venn diagram showing exclusive and shared genera of Chrysidoidea among conventional, agroforestry and transitional systems in the "Pontal do Paranapanema" region, São Paulo, Brazil. Bethylidae in blue, Chrysididae in red and Dryinidae in green color. parasitoids in Brazil, both in natural systems (Azevedo et al., 2002, 2003; Alencar et al., 2007) and in agricultural systems, including coffee crops and agroforestry (Perioto et al., 2004; Sperber et al., 2004; Ferreira et al., 2013; Lara et al., 2015). In our study, this family was more abundant in the agroforestry system, and three of the four genera occurred both in agroforestry and conventional systems (Fig. 3). These hymenopterans are ectoparasitoids of Lepidoptera and, mainly, Coleoptera that live in cryptic habitats (Evans, 1964; Azevedo \& Hermes, 1999; Azevedo et al., 2010, 2018; Morales-Silva et al., 2019). In agroforestry systems, the presence of different species of trees contribute to increasing the leaf litter stratum, which would consequently contribute to the cryptic habitat of the Bethylidae hosts.

Epyris Westwood was the most abundant genus of Bethylidae, collected in all the environments, representing approximately $69 \%$ of all individuals collected in the three systems (Fig. 3, Table 2). This genus presents several predator species of soil-dwelling beetle, like Tenebrionidae (Evans, 1964). The second genus with higher abundance was Dissomphalus Ashmead, representing approximately $23 \%$ of the total specimens collected, and found exclusively in the agroforestry system. Azevedo (2003) suggested that Dissomphalus is one of the most common genera of Bethylidae in the Neotropical Region, especially in rain forests. According to Evans (1964), Dissomphalus probably attacks small beetles, including certain myrmecophiles. The genus Bakeriella Kieffer occurred in both agroforestry and transitional systems. Their hosts are unknown (Azevedo, 2014). The genus Goniozus Förster occurred in the conventional and agroforestry systems (Fig. 3). This genus is associated to ectoparasitoids of microplepidopteran larvae (Morales-Silva et al., 2019). These last two genera were not very abundant in relation to the others bethylids collected, representing $1,7 \%$ of the total collected individuals (Table 2).

In Bethylidae, Cephalonomia stephanoderis Betrem and Prorops nasuta Waterston represent two of the most efficient parasitoids in the biological control of Hypothenemus hampei Ferrari (Coleoptera, Scolytidae), the most important coffee pest (Infante et al., 2001; Pérez-Lachaud et al., 2002). These parasitoids were introduced in coffee growing areas in Brazil in the 1990s to reduce the damage caused by $\mathrm{H}$. hampei (Infante et al., 2005; de Souza et al., 2006). None of these Bethylidae genera were recorded.

Chrysididae, in our study represented only by the subfamily Chrysidinae, differently than Bethylidae, was more abundant in the conventional systems, where also there were five exclusive genera (Fig. 3). Chrysidinae are parasitoids of solitary aculeate hymenopterans, such as Sphecidae, Apidae, Megachilidae, Halictidae and Vespidae. Little is known about host-parasite relationships of the neotropical Chrysididae (Kimsey, 2006; Pärn et al., 2015).

Dryinidae was represented by four subfamilies and five genera: Aphelopinae (Aphelopus Dalman), Anteoninae (Anteon Jurine and Deinodryinus Perkins), 
Dryininae (Dryinus Latreille) and Gonatopodinae (Gonatopus Ljungh). This family was a little more abundant in the conventional systems (Table 2), although no genus was found restrictively in the coffee monocultures. Dryinus was the only genus collected in the three types of ecosystems, while Deinodryinus was collected only in the agroforestry system (Fig. 3). These wasps are parasitoids and predators of Auchenorrhyncha (Hemiptera), and as many of the host species are considered pests in agriculture, the Dryinidae are considered beneficial insects (Guglielmino et al., 2013; Martins et al., 2020). There are some studies about records, descriptions of new species and associated hosts of Dryinidae fauna in different habits in Brazil, including Atlantic forest, Amazon forest and Cerrado savanna, but none of them focus on agroforestry systems (Martins, 2015, 2018, 2019; Martins \& Krinski, 2016; Martins \& Domahovski, 2017a, b; Versuti et al., 2014; Martins et al., 2015a, b, 2020).

Host-parasitoid-plant interactions are highly impacted by environmental structure and complexity. The movement of herbivores, their length of stay, abundance and mortality are directed associated with the structure of the vegetation. These factors, in turn, are important for the occurrence, prevalence and diversity of the associated parasitoid fauna (Obermaier et al., 2008). Azevedo (2003) indicates the preference of Dissomphalus in humid regions or with denser vegetation cover, which the agroforestry systems can better provide in relation to the coffee systems, for example. On the other side, some studies indicate the preference of some solitary wasps and bee species in more open areas, probably because these habitats can create favorable conditions for the location of prey and there are more nests sites available for ground nested species (Klein et al., 2002; Buschini \& Woiski, 2008; McCravy et al., 2009). Also, there are some studies demonstrating the importance of the pollination performed by wild and managed bees in Coffea arabica (see Macedo et al., 2020). As the Chrysidinae are parasitoids of the solitary aculeate hymenopterans, the high number of genera found in the conventional system alone or in both conventional and agroforestry is probably related to their hosts available in such systems.

According to Jose (2012), agroforestry plays certain roles in conserving biodiversity, such as providing habitat for species that can tolerate disturbance levels, providing ecological corridors between habitat remnants, and protecting ecosystems services as erosion control and water recharge. Because of the structural complexity of agroforestry systems, some studies demonstrate that they can maintain a high conservation potential, sometimes with even higher species richness levels of certain taxonomic groups when compared with native systems (Schulze et al., 2004; Pineda et al., 2005; Lima et al., 2014).

All the Chrysidoidea families registered in this study are poorly known in the Neotropical Region. In fact, there are no identification keys or taxonomical revisions for most of the genera of these families. Although we did not identify the individuals to the specific level, we believe this study is extremely important since it is one of the fewest to investigate such patterns with the Chrysidoidea in the southeastern region of Brazil. Furthermore, we strongly encourage taxonomic studies involving these taxa, so that the gaps related to their biology begin to be better explored.

\section{AUTHOR'S CONTRIBUTION}

PRL collected the specimens; ALM: identified the specimens. All authors wrote, reviewed, edited the manuscript and approved its final version.

\section{ACKNOWLEDGEMENTS}

Many thanks to Instituto Nacional de Ciência e Tecnologia dos Hymenoptera Parasitoides da Região Sudeste Brasileira (INCT - Hympar/Sudeste - CNPq/ FAPESP/CAPES) for financial support. A special thanks to Dr. Daercio Lucena for the identification of the Chrysididae. Many thanks to CNPq (Conselho Nacional de Desenvolvimento Científico e Tecnológico) for fellowship provided to ALM (grant \#151827/2019-2), CAPES (Coordenação de Aperfeiçoamento de Pessoal de Nível Superior) for fellowship provided to JRAL (grant \#88882.382399/2019-01) and FAPESP (Fundação de Amparo à Pesquisa do Estado de São Paulo) for fellowship provided to PRL (grant \#2010/07119-5). Many thanks to the anonymous reviewers for their critical reading and helpful comments.

\section{REFERENCES}

Alencar, I.D.C.C.; Fraga, F.B.; Tavares, M.T. \& Azevedo, C.0. 2007. Perfil da fauna de vespas parasitóides (Insecta, Hymenoptera) em uma área de Mata Atlântica do Parque Estadual de Pedra Azul, Domingos Martins, Espírito Santo, Brasil. Arquivos do Instituto Biológico, 74(2): 111-114.

Altieri, M. 2012. Agroecologia: bases científicas para uma agricultura sustentável. 3. ed. São Paulo, Ed. Expressão Popular. 400p.

Azevedo, C.0. 2003. Synopsis of the neotropical Dissomphalus (Hymenoptera, Bethylidae). Zootaxa, 338: 1-74.

Azevedo, C.0. 2014. Synopsis of Bakeriella Kieffer, 1910 (Hymenoptera, Bethylidae). Zootaxa, 3878(6): 501-535.

Azevedo, C.0. \& Hermes, J.L. 1999. Ecologia de comunidade de Bethylidae (Hymenoptera, Chrysidoidea) da Reserva Ecológica do Roncador, Brasília, Distrito Federal, Brasil. Revista Brasileira de Zoologia, 16(4): 1115-1126.

Azevedo, C.0. \& Santos, H.S. 2000. Perfil da fauna de himenópteros parasitóides (Hymenoptera) em uma área de Mata Atlântica da Reserva Biológica de Duas Bocas, Cariacica, ES, Brasil. Boletim do Museu de Biologia Mello Leitão, 11/12: 117-126.

Azevedo, C.0.; Alencar, I.D.C.C. \& Barbosa, D.N. 2010. Order Hymenoptera, family Bethylidae. In: Van Harten, A. (Ed.). Arthropod fauna of the UAE. Sharjah, UAE, UAE Insect Project. v. 3, p. 388-411.

Azevedo, C.0.; Alencar, I.D.C.C.; Ramos, M.S.; Barbosa, D.N.; Colombo, W.D.; Vargas R.; J.M. \& Lim, J. 2018. Global guide of the flat wasps (Hymenoptera, Bethylidae). Zootaxa, 4489(1): 1-294.

Azevedo, C.0.; Corrêa, M.S.; Gobbi, F.T.; Kawada, R.; Lanes, G.0.; Moreira, A.R.; Redighieri, E.S.; Santos, L.M. \& Waichert, C. 2003. Perfil das famílias de vespas parasitoides (Hymenoptera) em uma área de Mata Atlântica da 
Estação Biológica de Santa Lúcia, Santa Teresa, ES, Brasil. Boletim Museu Biológico Mello Leitão, 16: 39-46.

Azevedo, C.0.; Helmer, J.L. \& Barreto, F.C.C. 2006. Análise da fauna de Bethylidae (Hymenoptera, Chrysidoidea) de oito localidades do Paraná, Brasil. Boletim Museu Biológico Mello Leitão, 20: 83-94.

Azevedo, C.0.; Kawada, R.; Tavares, M.T. \& Perioto, N.W. 2002. Perfil da fauna de himenópteros parasitóides (Insecta, Hymenoptera) em uma área de Mata Atlântica do Parque Estadual da Fonte Grande, Vitória, ES, Brasil. Revista Brasileira de Entomologia, 46(2): 133-137.

Azevedo, C.O.; Molin, A.D.; Penteado-Dias, A.; Macedo, C.C.; Rodriguez-V, B.; Dias, B.Z.K.; Waichert, C.; Aquino, D.; Smith, D.R.; Shimbori, E.M.; Noll, F.B.; Gibson, G.; Onody, H.C.; Carpenter, J.M.; Lattke, J.E.; Ramos, K.S.; Williams, K.; Masner, L.; Kymsey, L.S.; Tavares, M.T.; Olmi, M.; Buffington, M.0.; Sharkey, M.; Johnson, N.F.; Kawada, R.; Gonçalves, R.B.; Feitosa, R.M.; Heydon, S.; Guerra, T.M.; Silva, T.S.R. \& Costa, V. 2015. Checklist of the genera of Hymenoptera (Insecta) from Espírito Santo state, Brazil. Boletim do Museu de Biologia Mello Leitão, 37(3): 313-343.

Brothers, D.J. 2006. Superfamília Chrysidoidea. In: Fernández, F. \& Sharkey, M.J. Introducción a los Hymenoptera de la Región Neotropical. Bogotá, Sociedad Colombiana de Entomología y Universidad Nacional de Colombia, cap. 30, p. 385-387.

Buschini, M.LT. \& Woiski, T.D. 2008. Alpha-beta diversity in trap-nesting wasps (Hymenoptera: Aculeata) in Southern Brazil. Acta Zoologica, 89: 351-358.

Chény, C.; Zuillam, E.; Nel, A. \& Perrichot, V. 2020. A new species of Ampulicomorpha Ashmead from Eocene French amber, with a list of fossil and extant Embolemidae (Insecta: Hymenoptera) of the world. Bulletin de la Sociétè Geologique de France. Earth Sciences Bulletin, 191: 1-7.

Engel, V.L. 1999. Introdução aos Sistemas Agroflorestais. FEPAF, Botucatu.

Evans, H.E. 1964. A synopsis of the American Bethylidae (Hymenoptera, Aculeata). Bulletin of the Museum of Comparative Zoology at Harvard College, 132: 1-222.

Fernandes, D.R.R.;Oliveira, A.L.;Martins, A.L.;Versuti, D.R.;Tango, M.F.A.; Lara, R.I.R. \& Perioto, N.W. 2012. Parastoides e predadores (Hymenoptera) associados a insetos-praga de cafeeiros no Brasil. In: Busoli, A.C.; Grigolli, J.F.J.; Souza, L.A.; Kubota, M.M.; Costa, E.N.; Santos, L.A.O.; Netto, J.C. \& Viana, M.A. Tópicos em Entomologia Agrícola - V. Jaboticabal, Maria de Lourdes Brandel. cap. 19, p. 251-270.

Fernández, F. 2006. Sitemática de los himenópteros de la región Neotropical: estado del conocimento y perspectivas. In: Fernández, F.; Sharkey, M.J. Introducción a los Hymenoptera de la región neotropical. Bogotá, Sociedad Colombiana de Entomología y Universidad Nacional de Colombia, cap. 2, p. 7-35.

Ferreira, F.Z.; Silveira, L.C.P. \& Haro, M.M. 2013. Families of Hymenopteran parasitoids in organic coffee cultivation in Santo Antônio do Amparo, MG, Brazil. Coffee Science, 8(1): 1-4.

Foley, J.A.; Ramankutty, N.; Brauman, K.A.; Cassidy, E.S.; Gerber, J.S.; Johnston, M.; Mueller, N.D.; O'Connell, C.; Ray, D.K.; West, P.C.; Balzer, C.; Bennett, E.M.; Carpenter, S.R.; Hill, J.; Monfreda, C.; Polasky, S.; Rockström, J.; Sheehan, J.; Siebert, S.; Tilman, D. \& Zaks, D.P.M. 2011. Solutions for a cultivated planet. Nature, 478(7369): 337-342.

Guglielmino, A.; Olmi, M. \& Bückle, C. 2013. An updated host-parasite catalogue of world Dryinidae (Hymenoptera: Chrysidoidea). Zootaxa, 3740: 1-113.

Haddad, N.M.; Brudvig, L.A.; Clobert, J.; Davies, K.F.; Gonzalez, A.; Holt, R.D.; Lovejoy, T.E.;Sexton, J.0.; Austin, M.P.; Collins, C.D.; Cook, W.M.; Damschen, E.I.; Ewers, R.M.; Foster, B.L.; Jenkins, C.N.; King, A.J.; Laurance, W.F.; Levey, D.J.; Margules, C.R.; Melbourne, B.A.; Nicholls, A.O.; Orrock, J.L.; Song, D.-X. \& Townshend, J.R. 2015. Habitat fragmentation and its lasting impact on Earth's ecosystems. Science Advances, 1(2): e1500052.
Hanson, P.E. \& Gauld, I.D. 2006. Introducíon. In: Hymenoptera de la Región Neotropical. Gainesville, American Entomological Institute. cap. 1, p. 1-5.

Heraty, J.; Ronquist, F.; Carpenter, J.M.; Hawks, D.; Schulmeister, S.; Dowling, A.P.; Murray, D.; Munro, J.; Wheeler, W.C.; Schiff, N. \& Sharkey, M. 2011. Evolution of the Hymenopteran Megaradiation. Molecular Phylogenetics and Evolution, 60(1): 73-88.

Infante, F.; Mumford, J. \& Baker, P. 2005. Life history of Prorops nasuta, a parasitoid of the coffee berry borer. BioControl, 50(2): 259-270.

Infante, F.; Mumford, J.; Baker, P.; Barrera, J. \& Fowler, S. 2001. Interspecific competition between Cephalonomia stephanoderis and Prorops nasuta (Hym., Bethylidae), parasitoids of the coffee berry borer, Hypothenemus hampei (Col., Scolytidae). Journal of Applied Entomology, 125(1-2): 63-70.

Jose, S. 2012. Agroforestry for conserving and enhancing biodiversity. Agroforestry Systems, 85(1): 1-8.

Kimsey, L.S. 2006. Família Chrysididae. In: Fernández, F. \& Sharkey, M.J. Introducción a los Hymenoptera de la Región Neotropical. Sociedad Colombiana de Entomologia and Universidad Nacional de Colombia, Bogotá, cap. 36, p. 419-426.

Klein, A.M.; Stefan-Dewenter, I.; Buchori, D. \& Tscharntke, T. 2002. Effects of Land-Use Intensity in Tropical Agroforestry Systems on Coffee FlowerVisiting and Trap-Nesting Bees and Wasps. Conservation Biology, 16(4): 1003-1014

Lara, R.I.R.; Fernandes, D.R.R.; Versuti, D.R.; de Tango, M.F.A. \& Perioto, N.W. 2015. Sampling and diversity of Hymenoptera (Insecta) in an orange orchard/Brazilian Savannah Fragment Interface. EntomoBrasilis, 8(1): 51-57.

Lima, F.A.X.; Pires, M.L.L.S. \& Vargas, L.P. 2014. Do convencional ao agroecológico: a experiência de Santa Cruz da Baixa Verde - Sertão de Pernambuco. Revista Brasileira de Agroecologia, 9(3): 3-20.

Lopes, P.R.; Araújo, K.C.S.; Ferraz, J.M.G.; Lopes, I.M. \& Fernandes, L.G. 2012. Produção de café agroecológico no sul de Minas Gerais: sistemas alternativos à produção intensiva em agroquímicos. Revista Brasileira de Agroecologia, 7(1): 25-38

Lopes, P.R.; Kageyama, P.Y. \& Lopes, K.C.S.A. 2014. Sistemas agroflorestais e produção agroecológica de café na região do pontal do Paranapanema. Retratos de Assentamentos, 17(1): 261-292.

Macedo, J.; Viana, B.; Freitas, B.; Medeiros, A.; Kevan, P.G. \& Vergara, C.H. 2020. The Potential of Bee Vectoring on Coffee in Brazil. In: Smagghe, G.; Boecking, 0.; Maccagnani, B.; Mänd, M. \& Kevan, P.G. Entomovectoring for precision biocontrol and enhanced pollination of Crops. Switzerland, Springer. p. 165-181.

Martínez-Salinas, A. 2016. The role of agroforestry in biodiversity conservation and ecosystem service provisioning. Agriculture for Development, 28: 15-16.

Martins, A.L. 2015. Anew species of Deinodryinus Perkins, 1907 (Hymenoptera, Dryinidae) from Minas Gerais, Brazil. Zootaxa, 4032(2): 236-240.

Martins, A.L. 2018. A new species of Esagonatopus Olmi (Hymenoptera, Dryinidae) from Central Brazil. Zootaxa, 4379(3): 441-444.

Martins, A.L. 2019. New record of the rare Gonatopus mariae Martins, Lara, Perioto \& Olmi, 2015 (Hymenoptera, Dryinidae) for the state of Espírito Santo, Brazil. Check List, 15(4): 691-694.

Martins, A.L. \& Domahovski, A.C. 2017a. Redescription and biology of Gonatopus amazonicus Olmi (Hymenoptera, Dryinidae) from Southern Brazil. Zootaxa, 4324(3): 592-596.

Martins, A.L. \& Domahovski, A.C. 2017b. New record of Gonatopus flavoniger Olmi, 1991 (Hymenoptera: Dryinidae) from Paraná, Brazil, with notes on some aspects of its biology and morphology. Check List, 13(4): 95-99.

Martins, A.L. \& Krinski, D. 2016. First record of the parasitoid Gonatopus flavipes Olmi, 1984 (Hymenoptera, Dryinidae) in Brazil's Amazon forest. Journal of Hymenoptera Research, 50: 91-196. 
Martins, A.L.; Domahovski, A.C. \& Rendón-Mera, D.I. 2020. Sexual association and cicadellid hosts of Dryinidae (Hymenoptera, Chrysidoidea): description of five new species from Brazil and a synopsis of the interaction with Gyponini (Hemiptera, Membracoidea). Insect Systematics \& Evolution, 1(aop): 1-34. D0I

Martins, A.L.; Lara, R.I.R. \& Perioto, N.W. 2015a. New records of Dryinidae (Hymenoptera: Chrysidoidea) from the Atlantic Rainforest of São Paulo, Brazil. Pan-Pacific Entomologist, 91(2): 196-199.

Martins, A.L.; Lara, R.I.R.; Perioto, N.W. \& Olmi, M. 2015b. Two new species of Dryinidae (Hymenoptera: Chrysidoidea) from areas of Atlantic Rainforest at São Paulo State, Brazil. Brazilian Journal of Biology, 75(2): 455-459.

McCravy, K.W.; Bara, J.J.; Hessler, S.N.; Luxmore, L.K.; Stinebaker, K.S. \& Jenkins, S.E. 2009. Abundance and diversity of thread-waisted Wasps (Hymenoptera: Sphecidae: Sphecinae) at Alice L. Kibbe Life Science Station, Hancock County, Illinois USA. Transactions of the Illinois State Academy of Science, 102: 107-115.

McGinty, M.M.; Swisher, M.E. \& Alavalapati, J. 2008. Agroforestry adoption and maintenance: self-efficacy, attitudes and socio-economic factors. Agroforestry Systems, 73(2): 99-108.

Meirelles, L.R. 2003. Revista dos Sistemas Agroflorestais. Dom Pedro de Alcântara/RS, Centro Ecológico/Litoral Norte. 60p.

Melo, G.A.R.; Aguiar, A.T. \& Garcet-Barrett, B.R. 2012. Hymenoptera. In: Rafael, J.A.; Melo, G.A.R.; Carvalho, C.J.B.; Casari, S.A. \& Constantino, R. Insetos do Brasil: diversidade e taxonomia. Ribeirão Preto, Editora Holos. Cap. 35, p. 553-612.

Morales-Silva, T.; Maia, L.F.; Martins, A.L. \& Modesto-Zampieron, S.L. 2019. Herbivore, parasitoid and hyperparasitoid insects associated with fruits and seeds of Enterolobium contortisiliquum (Vell.) Morong (Fabaceae). Brazilian Journal of Biology, 79(3): 369-376.

Nakayama, K.; Azevedo, C.0.; Valverde, M.0.; de Siqueira Neves, F. \& Sperber, C.F. 2008. Sampling parasitoid wasps (Insecta, Hymenoptera) in cacao agroforestry systems. Studies on Neotropical Fauna and Environment, 43(3): 217-226.

Negawo, W.J. \& Beyene, D.N. 2017. The role of coffee based agroforestry system in tree diversity conservation in Eastern Uganda. Journal of Landscape Ecology, 10(2): 1-18.

Obermaier, E.; Heisswolf, A.; Poethke, H.J.; Randlkofer, B. \& Meiners, T. 2008. Plant architecture and vegetation structure: Two ways for insect herbivores to escape parasitism. European Journal of Entomology, 105: 233-240.

Olmi, M. \& Virla, E.G. 2014. Dryinidae of the Neotropical region (Hymenoptera: Chrysidoidea). Zootaxa, 3792(1): 1-534.

Olmi, M.; Copeland, R.S. \& Noort, S.V. 2019. Dryinidae of the Afrotropical region (Hymenoptera, Chrysidoidea). Zootaxa, 4630(1): 1-619.

Paludo, R. \& Costabeber, J.A. 2012. Sistemas agroflorestais como estratégia de desenvolvimento rural em diferentes biomas brasileiros. Revista Brasileira de Agroecologia, 7(2): 63-76.

Pärn, V.; Soon, V.; Vallis00, T.; Hovi, K. \& Luig, J. 2015. Host specificity of the tribe Chrysidini (Hymenoptera: Chrysididae) in Estonia ascertained with trap-nesting. European Journal of Entomology, 112(1): 91-99.

Pauli, T.; Castillo-Cajas, R.F.; Rosa, P.; Kukowka, S.; Berg, A.; Berghe, E.V.D.; Fornoff, F.;Hopfenmüller, S.; Niehuis, M.; Peters, R.S.; Staab, M.; Strumia, F.; Tischendorf, S.; Schmitt, T. \& Niehuis, 0. 2019. Phylogenetic analysis of cuckoo wasps (Hymenoptera: Chrysididae) reveals a partially artificial classification at the genus level and a species-rich clade of bee parasitoids. Systematic Entomology, 44: 322-335.

Pereira, H.M.; Leadley, P.W.; Proença, V.; Alkemade, R.; Scharlemann, J.P.W.; Fernandez-Manjarrés, J.F.; Araújo, M.B.; Balvanera, P.; Biggs, R.; Cheung,
W.W.L.; Chini, L.; Cooper, D.; Gilman, E.L.; Guénette, S.; Hurtt, G.C.; Huntington, H.P.; Mace, G.M.; Oberdorff, T.; Revenga, C.; Rodrigues, P.; Scholes, R.J.; Sumaila, U.R. \& Walpole, M. 2010. Scenarios for Global Biodiversity in the 21 ${ }^{\text {st }}$ Century. Science, 330(6010): 1496-1501.

Pérez-Lachaud, G.; Hardy, I.C.W. \& Lauchaud, J.-P. 2002. Insect gladiators: competitive interactions between three species of bethylid wasps attacking the coffee berry borer, Hypothenemus hampei (Coleoptera: Scolytidae). Biological Control, 25: 231-238.

Perioto, N.W.; Lara, R.I.R.; Selegatto, A. \& Luciano, E.S. 2004. Himenópteros parasitóides (Insecta: Hymenoptera) coletados em cultura de café Coffea arabica L. (Rubiaceae) em Ribeirão Preto, SP, Brasil. Arquivos do Instituto Biologico, São Paulo, 71: 41-44.

Pineda, E.; Moreno, C.; Escobar, F. \& Halffter, G. 2005. Frog, Bat, and Dung Beetle Diversity in the Cloud Forest and Coffee Agroecosystems of Veracruz, Mexico. Conservation Biology, 19(2): 400-410.

Rands, M.R.W.; Adams, W.M.; Bennun, L.; Butchart, S.H.M.; Clements, A.; Coomes, D.; Entwistle, A.; Hodge, I.; Kapos, V.; Scharlemann, J.P.W.; Sutherland, W.J. \& Vira, B. 2010. Biodiversity Conservation: Challenges Beyond 2010. Science, Washington, 329(5997): 1298-1303.

Schulze, C.H.; Waltert, M.; Kessler, P.J.A.; Pitopang, R.; Veddeler, D.; Mühlenberg, M.; Gradstein, S.R.; Leuschner, C.; Steffan-Dewenter, I. \& Tscharntke, T. 2004. Biodiversity indicator groups of tropical land-use systems: Comparing plants, birds, and insects. Ecological Applications, 14(5): 1321-1333.

Silva, A.A; Fernandes, B.M. \& Valenciano, R.C. 2006. Relatório de Impactos Socioterritoriais (RIST): Desenvolvimento territorial e políticas públicas no Pontal do Paranapanema. Presidente Prudente, Unesp.

de Souza, M.S.; Teixeira, C.A.D.; Azevedo, C.0.; Costa, V.A. \& Costa, J.N.M. 2006. Ocorrência de Cephalonomia stephanoderis Betrem (Hymenoptera: Bethylidae) em cafezais da Amazônia Brasileira. Neotropical Entomology, 35(4): 560-562.

Sperber, C.F.; Nakayama, K.; Valverde, M.J. \& Neves, F.S. 2004. Tree species richness and density affect parasitoid diversity in cacao agroforestry. Basic and Applied Ecology, 5(3): 241-251.

Steffan-Dewenter, I.; Kessler, M.; Barkmann, J.; Bos, M.M.; Buchori, D.; Erasmi, S.; Faust, H.; Gerold, G.; Glenke, K.; Gradsteind, S.R.; Guhardjai, E.; Harteveldd, M.; Herteld, D.; Höhn, P.; Kappash, M.; Köhler, S.; Leuschnerd, C.; Maertensj, M.; Marggrafe, R.; Migge-Kleiank, S.; Mogeai, J.; Pitopangl, R.; Schaeferk, M.; Schwarzem, S.; Spornd, S.G.; Steingrebek, A.; Tjitrosoedirdjoi, S.S.; Tjitrosoemitoi, S.; Twele, A.; Weberh, R.; Woltmannk, L.; Zeller, M. \& Tscharntkea, T. 2007. Tradeoffs between income, biodiversity, and ecosystem functioning during tropical rainforest conversion and agroforestry intensification. Proceedings of the National Academy of Sciences, 104(12): 4973-4978.

Townes, H.A. 1972. A light-weight Malaise trap. Entomological News, 83: 239-247.

Vargas-Rojas, J.M. \& Terayama, M. 2006. Família Bethylidae. In: Fernández, F. \& Sharkey, M.J. Introducción a los Hymenoptera de la Región Neotropical. Sociedad Colombiana de Entomología and Universidad Nacional de Colombia, Bogotá, cap. 37, p. 427-442.

Versuti, D.R.; de Paz, C.C.P.; Lara, R.I.R.; Fernandes, D.R.R. \& Perioto, N.W. 2014. Comparative abundance and diversity of Dryininae (Hymenoptera, Dryinidae) in three savannah phytophysiognomies in southeastern Brazil, under three sampling methods. Revista Brasileira de Entomologia, 58(3): 273-27.

Volsi, B.; Telles, T.S.; Caldarelli, C.E.; Regina, M. \& de Camara, G. 2019. The dynamics of coffee production in Brazil. PLOS ONE, 14(7): e0219742. DOI 